\title{
HISTOLOGY OF THE LIGHT ORGANS OF PHOLAS DACTYLUS (LAMELLIBRANCHIA)
}

\author{
By J. A. C. Nicol \\ The Plymouth Laboratory \\ (Plate I and Text-fig. I)
}

The piddock, Pholas dactylus L., gives off a luminous secretion when irritated. The luminous glands which produce the secretion are two longitudinal stripes in the exhalant siphon, a pair of triangular organs in the mantle cavity near the base of the siphon, and a stripe around the ventral rim of the mantle (Panceri, I872).

The histology of the light-organs has been described several times. A light-organ is covered by a simple columnar ciliated epithelium, below which are many glandular cells, which discharge through the surface epithelium. The outer part of the glandular layer consists of a mass of large mucus cells. Deeper lies a second glandular region containing large cells with long necks that extend to the external epithelial surface. Dubois (1892, 1914, 1928) believed that the photogenic tissue was made up of two kinds of secretory cells; these were the superficial ciliated cells, which possessed glandular bases (fixed secretory cells); and deeper lying glandular cells derived from clasmatocytes (migratory secretory cells). Rawitz (I89I) clearly distinguished a mucous from an underlying photogenic layer. The latter, according to Förster (19I4), contains pyriform cells with long necks. He believed that he could distinguish a secretory cycle in the photogenic cells. Exhausted cells at the beginning of the cycle possessed an alveolar cytoplasm; granules began to appear in the cytoplasm; the granules increased in number and stained intensely with iron haematoxylin. Those photogenic cells which were filled with granules were in the active secretory state. Transitional stages between the inactive (or depleted) cells and the active (granular) cells were rare. An account by Dahlgren (I9I6) is based on the work of Förster (I9I4).

While examining some sections of the light-organs of Pholas, I made certain observations which differed from the published accounts. Moreover, the latter were difficult to reconcile with one another. Therefore, I undertook the following study of the light-organs of Pholas dactylus.

\section{METHODS}

The triangular organs and the siphonal cords were excised together with a little contiguous tissue. The material was fixed in Zenker's fluid, and cut in 
polyester wax (Steedman, 1957). Stains used were: thionin; Alcian blue and neutral red; mucicarmine; Giemsa; Masson's trichrome stain; van Gieson's stain; a modification of Masson's, consisting of Weigert's haematoxylin, aniline blue and xylidine ponceau; iron haematoxylin; Ehrlich's haematoxylin and eosin.

\section{OBSERVATIONS}

The general histological picture described by earlier workers is confirmed (Text-fig. I; P1. I). The epithelium overlying the light-organ, as elsewhere, contains ciliated columnar cells. Between them open the distal extremities of the underlying glandular cells. In vertical section, the ciliated epithelial cells expand externally into cones, which arch over the necks of the glandular cells. Underneath the epithelium is a thick and dense layer of mucus cells, some I80 $\mu$ deep, which extend down to and into the outer part of the photogenic layer (Text-fig. I; P1. I). These mucus cells are large, up to I80 $\mu$ long and

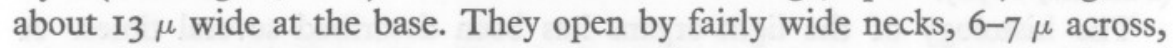
between the epithelial cells. Except for their very large size, these cells are typical mucus cells. Their staining affinities are listed in Table I. With some stains they are coloured much more intensely than the ordinary mucus goblet cells occurring elsewhere in the epithelium.

Below the mucus cells there is another dense glandular layer. This, the photogenic tissue, consists of closely packed secretory cells. They occupy a layer approximately $\mathrm{I} 20 \mu$ thick, beginning about $\mathrm{I} 60 \mu$ from the surface. Thus, the mucus layer and the photogenic layer overlap to some extent.

Two kinds of cells can be distinguished in the photogenic layer by their staining affinities (see Table I). Let these cells be known as types I and 2 (Text-fig. I). Both types of cells have granular contents. Photogenic cells of type I are more abundant (Text-fig. I; Pl. I). The granules are basophilic to some plasma stains: they stain weakly with iron haematoxylin and eosin, red with mucicarmine, green with light green, etc. Cells of type 2 are infrequent, relative to type I. Their coarse granules are acidophilic; they stain red with eosin, neutral red and xylidine ponceau, and possess stronger affinity for iron haematoxylin.

Photogenic cells, type I (Text-fig. I). These are packed closely together, up to $270 \mu$ long and $15 \mu$ wide at the base. They have the shape of long pyriform sacs with long necks, $4-5 \mu$ wide, extending to the epithelial surface. The small nucleus lies basally, either in the lateral wall or at the bottom of the cell. The interior of the cell is packed with coarse granules, having an average diameter of about $\mathrm{I} \cdot 3 \mu$. The cell is invested by a thin cytoplasmic sheath staining with xylidine ponceau. The secretory granules extend through the necks of the cells to the external surface; discharged to the exterior, they lose their identity. A homogeneous flocculent precipitate lies over the external surface of the epithelium. 
Photogenic cells, type 2 (Text-fig. I). These have about the same dimensions as cell type $\mathrm{I}$. They extend well down into the photogenic layer. At the base they are about II $\mu$ wide; the necks are $4.5 \mu$ wide where they pass through the epithelial layer. A small nucleus lies against the wall of the cell in the basal

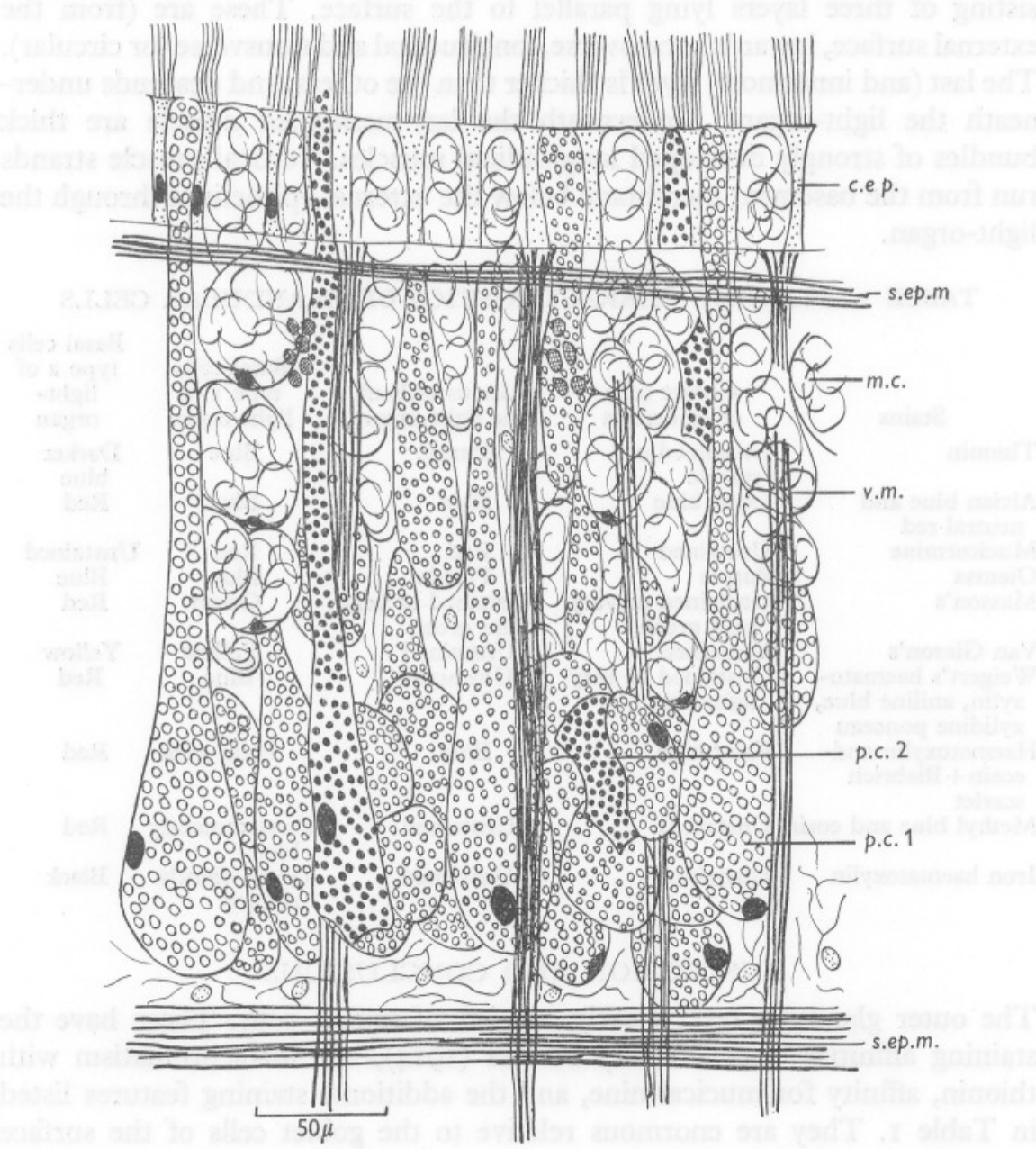

Text-fig. I. Semi-diagrammatic representation of the triangular light-organ of Pholas dactylus, from vertical sections. Legend: c.ep., ciliated epithelium; m.c., mucus cell; p.c. I., photogenic cell type I; p.c. 2, photogenic cell type 2 ; s.ep.m., subepithelial muscle; v.m., vertical muscle.

region. The interior of the cell is packed with coarse spherical granules, having an average diameter of about I'I $\mu$. They extend up to the external epithelium, where they can be seen emerging from the mouths of the cells. The cytoplasmic wall is difficult to distinguish. 
Previous workers (Dubois, 1892, 1914; Förster, 1914) have laid much emphasis on the muscle system in the vicinity of the light-organ. The following description is based on the siphonal cord (Text-fig. I; Pl. I), but the arrangement is similar in the triangular organ. There is a subepithelial muscle consisting of three layers lying parallel to the surface. These are (from the external surface, inwards), transverse, longitudinal and transverse (or circular). The last (and innermost) layer is thicker than the others, and descends underneath the light-organ. Underneath the last-mentioned muscle are thick bundles of strongly developed longitudinal muscles. Vertical muscle strands run from the basement membrane below the external epithelium through the light-organ.

TABLE 1. STAINING CHARACTERISTICS OF GLANDULAR CELLS

\begin{tabular}{|c|c|c|c|c|}
\hline Stains & $\begin{array}{l}\text { Goblet cells } \\
\text { of epidermis }\end{array}$ & $\begin{array}{l}\text { Mucus cells of } \\
\text { the light-organ }\end{array}$ & $\begin{array}{l}\text { Basal cells } \\
\text { type I of } \\
\text { light-organ }\end{array}$ & $\begin{array}{l}\text { Basal cells } \\
\text { type } 2 \text { of } \\
\text { light- } \\
\text { organ }\end{array}$ \\
\hline Thionin & $\begin{array}{l}\text { Unstained or } \\
\text { purple }\end{array}$ & Purple & Blue & $\begin{array}{l}\text { Darker } \\
\text { blue }\end{array}$ \\
\hline $\begin{array}{l}\text { Alcian blue and } \\
\text { neutral red }\end{array}$ & Light blue & Blue & Blue & Red \\
\hline $\begin{array}{l}\text { Mucicarmine } \\
\text { Giemsa }\end{array}$ & $\begin{array}{l}\text { Unstained } \\
\text { Purple }\end{array}$ & $\begin{array}{l}\text { Red } \\
\text { Purple }\end{array}$ & $\begin{array}{l}\text { Red } \\
\text { Blue }\end{array}$ & $\begin{array}{c}\text { Unstained } \\
\text { Blue }\end{array}$ \\
\hline Masson's & $\begin{array}{l}\text { Unstained or very } \\
\text { faint green }\end{array}$ & $\begin{array}{l}\text { Unstained or very } \\
\text { faint green }\end{array}$ & Green & Red \\
\hline Van Gieson's & Unstained & Unstained & Yellow & Yellow \\
\hline $\begin{array}{l}\text { Weigert's haemato- } \\
\text { xylin, aniline blue, } \\
\text { xylidine ponceau }\end{array}$ & $\begin{array}{l}\text { Unstained or very } \\
\text { light blue }\end{array}$ & Unstained & Blue & Red \\
\hline $\begin{array}{l}\text { Haematoxylin and } \\
\text { eosin + Biebrich } \\
\text { scarlet }\end{array}$ & Faint blue & Blue & Faint pink & Red \\
\hline Methyl blue and eosin & Unstained & Unstained & Predominantly & Red \\
\hline Iron haematoxylin & Unstained & Unstained & $\begin{array}{l}\text { Grey-faintly } \\
\text { stained }\end{array}$ & Black \\
\hline
\end{tabular}

The outer glandular layer clearly consists of mucus cells. These have the staining affinities discovered by Förster (I9I4), viz. metachromatism with thionin, affinity for mucicarmine, and the additional staining features listed in Table I. They are enormous relative to the goblet cells of the surface epithelium elsewhere. Moreover, there are differences in the staining affinities of these two types of mucus cells, since the mucinogen of the ordinary goblet cells stains poorly or not at all with thionin and mucicarmine. Possibly, different types of mucins are produced by goblet cells of the epithelium and mucus cells of the light-organ. Certainly, the large size and numerical abundance of these cells in the light-organs indicate that they are concerned with photogeny, and their functional role may be to produce a mucin-carrier for the photogenic secretion. 
There are two kinds of secretory cells in the lower glandular or photogenic layer. Both types of cells are filled with granular inclusions which differ in staining affinities. As a generalization, the granules of cell type $\mathrm{I}$ have rather poor staining affinities; those of cell type 2 are acidophilic and have strong staining affinities. The staining characteristics allow the two kinds of cells to be distinguished clearly from each other. Cells of both types can be seen discharging through the external epithelium.

Förster's interpretation of a transformation in the photogenic cells from an alveolar to a granular condition seems to be based on failure to distinguish two kinds of secretory cells in the inner glandular or photogenic layer. Dahlgren (I9I6) accepted Förster's account, and his artist clearly illustrated two kinds of cells in the photogenic layer, viz. alveolar cells with a coarse meshwork and cells with darkly staining small granules. The latter, presumably, were stained with iron haematoxylin (cf. elsewhere in Dahlgren's work). The alveoli appear to be unstained granules of cell type $\mathrm{I}$, and are grossly exaggerated in size. A most interesting feature of Dahlgren's illustration is that the alveolar cells (photogenic cells, type I) are shown discharging at the surface; granules of the other kind of cell (photogenic cells, type 2) are shown as extending along the neck of the cell to the external surface.

Förster (I9I4) considered that the outer glandular layer (of mucus cells) was concerned solely with the production of mucus. Dubois (I892, I914) demonstrated the basic luciferin-luciferase reaction in the secretion of Pholas (cf. Harvey, 1957). Dahlgren (I9I6), without evidence, assigned luciferin to granular cells of the inner glandular (i.e. photogenic) layer, luciferase to the outer glandular (i.e. mucus) layer. Since there are two kinds of secretory cells in the photogenic layer, it is logical to link them with the production of luciferin and luciferase; possibly, the luciferase corresponds to the eosinophilic granules of less abundant cell type 2 . This is mere speculation, however.

Previous authors (Dubois, I9I4; Förster, 1914) have assumed that the luminous secretion of Pholas is discharged by muscular contraction. The luminous gland cells of Pholas much resemble those of Chaetopterus. The latter discharges a luminous secretion from unicellular glands, and its photogenic tissue lacks muscle fibres. In both animals the luminescence is under nervous control; the gland cells are filled with granules, and these emerge through an open pore at the apex of the cell. Instead of invoking a muscular mechanism, I would suggest that the walls of these cells consist of oriented contractile protein capable of expressing the cell contents. A model may be found in the contractile behaviour of monolayers of actomyosin (Bennett, I956; Giese, I957).

I am grateful to Mr A. C. G. Best for the excellent histological preparations and for the photography. 


\section{SUMMARY}

Earlier work dealing with the histology of the light-organs of Pholas dactylus is reviewed.

Beneath the surface epithelium of the light-organ, two glandular layers can be distinguished. One, an outer glandular layer, contains mucus cells. The other, an inner layer, contains two kinds of granular cells, which can be separated by their staining characteristics. The latter are listed in Table I. Both kinds of granular cells of the inner layer discharge their contents upon the external surface. The photogenic secretions are produced, most probably, by the glandular cells of the inner layer.

\section{REFERENCES}

BENNETT, H. S., I956. The concepts of membrane flow and membrane vesiculation as mechanisms for active transport and ion pumping. F. biophys. biochem. Cytol., Vol. 2, pp. 99-103.

DAHLGREN, U., I9I6. Production of light by animals. Light production among the lower molluscs. F. Franklin Inst., Vol. I81, pp. 386-400.

Dubors, R., 1892. Anatomie et physiologie comparées de la Pholade dactyle. Ann. Univ. Lyon, Vol. 2, 2 Fasc., 167 pp.

— I9I4. La vie et la lumière, $338 \mathrm{pp}$. Paris: Félix Alcan.

1928. Lumière (Production de la) ou Biophotogénèse. In C. Richet's Dictionnaire de Physiologie, T. I0, pp. 277-394. Paris: Félix Alcan.

FörsTER, J., I9I4. Über die Leuchtorgane und das Nervensystem von Pholas dactylus. Z. wiss. Zool., Bd. 109, pp. 349-92.

GIese, A. C., I957. Cell Physiology. 534 pp. Philadelphia and London: W. B. Saunders Co.

HARVEY, E. N., 1957. A history of luminescence from the earliest times until 1900. Mem. Amer. phil. Soc., Vol. 44, 692 pp.

PANCERI, P., I872. The luminous organs and the light of pholades. Quart. F. micr. Sci., Vol. I2, pp. 254-60.

RawrTz, B., I891. Der Mantelrand der Acephalen. Dritter Teil. Siphonata. Epicuticulabildung. Allgemeine Betrachtungen. Fena. Z. Naturw., Bd. 27, pp. I-232.

SteEDMAN, H. F., 1957. Polyester wax. A new ribboning embedding medium for histology. Nature, Lond., Vol. 179, p. 1345.

\section{EXPLANATION OF PLATE I}

Plate I. A. General view of a triangular light organ of Pholas dactylus. Iron haematoxylin, acid fuchsin-ponceau $2 \mathrm{R}$, aniline blue. Mucus cells unstained; photogenic cells dark. B. View of siphonal light-organ, showing mucus cells. Giemsa. Legend: l.o., light organ. m., muscle. c.ep., ciliated epithelium. m.c., mucus cells. p.c. I, p.c. 2, photogenic cells, types $\mathrm{I}$ and 2, respectively. p.l., photogenic layer. Mucus cells dark; photogenic cells, type I, light; photogenic cells, type 2 , with dark granules. 


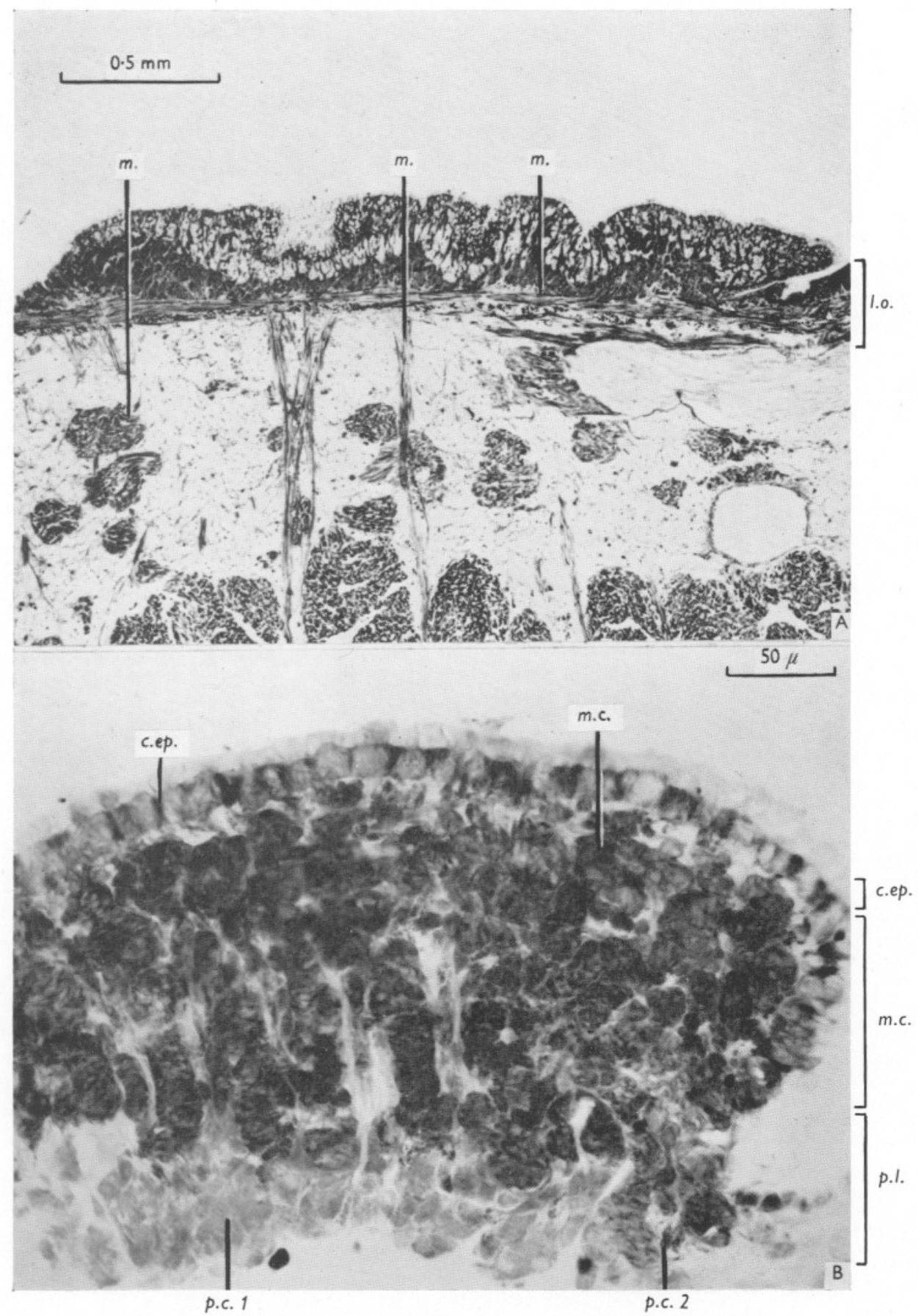

(Facing p. I I4) 